\title{
CESARZOWA CIXI W NOWYM ŚWIETLE
}

Jung Chang, Cesarzowa wdowa Cixi. Konkubina, która stworzyła współczesne Chiny (Empress Dowager Cixi. The Concubine who Launched Modern China, 2013), tłum. Anna Gralak, Wydawnictwo Znak, Kraków 2015, ss. 496.

Cesarzowa Cixi (1835-1908) rządziła w Chinach u schyłku mandżurskiej dynastii Qing (1644-1911). W ciągu pierwszych 150 lat panowania Qingów - do końca XVIII w. - dynastia ta zapewniła cesarstwu chińskiemu powiększenie terytorium i rozwój. Po sześcdziesięcioletnim panowaniu cesarza Qianlonga, którego następcy nie dorównywali mu talentami, w Chinach nastąpił zastój, a po wojnach opiumowych powolny upadek kraju, wstrząsanego powstaniami chłopskimi i atakowanego przez obce państwa. W $1851 \mathrm{r}$. pochodząca z rodziny mandżurskich urzędników Cixi została wybrana na jedną z konkubin cesarza Xianfenga. Początkowo miała niższą rangę, ale po urodzeniu w 1856 r. syna - jedynego męskiego potomka cesarza - awansowała i zajęła pozycję równorzędną z bezdzietną oficjalną cesarzową. Wraz z nią sprawowała od śmierci Xianfenga w 1862 r. do 1873 r. regencję w imieniu małoletniego syna, późniejszego cesarza Tongzhi. Po jego niewyjaśnionej śmierci w 1875 r. ponownie objęła regencję, tym razem w imieniu osadzonego na tronie czteroletniego siostrzeńca Guangxu. Funkcję regentki sprawowała przez 12 lat, lecz przez następne niemal dwie dekady, aż do śmierci w 1908 r., wciąż miała decydujący wpływ na państwo, a od 1898 r., po epizodzie „100 dni reform" i odsunięciu od władzy cesarza Guangxi faktycznie rządziła w Chinach. 
Obszerna książka Jung Chang jest próbą rewizji ocen Cixi i jej roli w historii Chin, wykazującą niesłuszność często wypowiadanych negatywnych opinii o osobie cesarzowej i sprawowanych przez nią rządach. Autorka konfrontuje przyjęty wizerunek cesarzowej wdowy jako egoistki, trzymającej się kurczowo władzy wyłącznie w celu zachowania swojego stanu posiadania, bezwzględnej wobec poddanych, z obrazem osoby kierującej się interesami państwa i dostrzegającej potrzebę zapewnienia mu stabilnych rządów w trudnych czasach, przy oczywistym utożsamianiu państwa z dynastią. Założenie słuszne, jeśli przyjąć, że wśród historycznych przesłanek czarnej legendy Cixi główną rolę odegrało postrzeganie dynastii Qing jako obcego panowania, które można łatwo obwiniać o postępujący od połowy XIX w. upadek potęgi Chin z powodu braku patriotycznego zaangażowania.

Prezentowana narracja nie daje podstaw do podsycanej przez nacjonalizm niechęci wobec dynastii najeźdźców, pomijającej m.in. fakt, że Mandżurowie przejęli formy administracji poprzedniej dynastii Ming (np. duża rola eunuchów, którzy w wielu funkcjach zastąpili aparat urzędniczy dworu). Podkreśla przede wszystkim, że władcy dynastii Qing rządzili cesarstwem na zasadach konfucjańskich (utrzymanie konfucjańskiego systemu selekcji urzędników czy znamienny nacisk na konfucjańską edukację małoletniego Guangxu). Zgodnie z nimi uważali Chiny za państwo panujące nad uniwersum, co determinowało postrzeganie świata zewnętrznego i kontaktów z nim jako niepotrzebnych cesarstwu. W tym kwestionowanym przez autorkę negatywnym osądzie Mandżurów pomija się także fakt ich kulturowego zasymilowania, którego licznych przykładów książka dostarcza.

Dla rodzących się na przełomie XIX i XX w. środowisk chińskich postępowych patriotów konkluzja o wyczerpaniu się zastanej formuły cesarstwa jako ustroju państwa nieadekwatnego do ówczesnych warunków była łatwiejsza do przyjęcia z dodaniem przymiotnika „mandżurskie”. Cixi to cesarstwo przez pół wieku uosabiała. Autorka przyjmuje punkt widzenia dynastii, dowodząc, że czarna legenda cesarzowej wyrosła w latach triumfu po obaleniu monarchii na podstawie uproszczonych i - jak twierdzi autorka - zafałszowanych relacji, wśród których za wyjątkowo perfidne uważa te tworzone przez Kang Youweia i Liang Qichao'.

Poza potrzebą odwetu na Mandżurach szczególną rolę w powstaniu negatywnego wizerunku Cixi odgrywały tradycyjne uprzedzenia wobec kobiet. Wątek ,feministyczny" - potrzeba zwrócenia uwagi na niezwykłość cesarzowej, potrafiącej

${ }^{1}$ Na s. 326-327 autorka pisze: ,[Kang] był doskonałym mitotwórcą i propagandystą - on i Liang sławili samych siebie i niestrudzenie szkalowali Cixi, wymyślając liczne odpychające historie na jej temat i powtarzając je w wywiadach, przemówieniach i pismach (...), oskarżali Cixi o otrucie cesarzowej Zhen, doprowadzenie do śmierci własnego syna, zmuszenie wdowy po nim do samobójstwa (...). Prawie wszystkie oskarżenia, które kształtowały publiczny wizerunek Cixi, zrodziły się w jego umyśle. To on pierwszy przedstawił Cixi jako rozpustną despotkę (...). Ludzie wierzyli Kangowi (...)”. 
działać wbrew wszystkim ograniczeniom narzuconym kobietom w „cywilizacji, która traktowała kobiety z niezrównanym okrucieństwem" (s. 434) - to jeden z głównych nurtów analizy autorki. Dokumentuje go m.in. świadomością swojej bohaterki dotyczące koniecznego przezwyciężania podstawowego z ograniczeń braku wykształcenia, wynikającego z niedopuszczania kobiet, bez względu na ich status społeczny, do edukacji. Cixi, już jako regentka, starała się uczyć, korzystając z pomocy wykształconych eunuchów, znowu - jedynej formy edukacji dostępnej dla kobiety w Zakazanym Mieście (s. 88). Pozycję kobiet i pozbawianie ich możliwości zdobycia wykształcenia jako motyw podjęcia pracy nad postacią Cixi autorka wspomniała w rozmowie z dziennikarką Radia Tok FM (audycja nadana 6 września 2015 r.), przypominając historie kobiet w swojej rodzinie - babki i matki - przejmująco opowiedziane w jej pierwszej książce Dzikie łabędzie.

Czarna legenda szczególnie bujnie rozwinęła się w przekazie ustnym i w powielających ją później sfabularyzowanych, graniczących z sensacją książkach czy w nowszych czasach w filmach, w których rozbudowane opowieści o dworskich intrygach, pławieniu się w zbytku itp. łatwo zapadały w pamięć i zapewniały popularność. Można przytoczyć przykład wydanej w polskim przekładzie ćwierć wieku temu książki Ostatni cesarze Chin Wasilija Sidichmienowa, gdzie wiele ciekawie podanych faktów przeplata się z bulwersującymi szczegółami obyczajowymi i skandalami. Z nowszych publikacji - poświęconą Cixi (niedopracowaną) notkę w świetnej Historii Chińczyków z serii pomocników historycznych „Polityki” (s. 67). Negatywnemu wizerunkowi przeciwstawiła się autorka Cesarzowej Orchidei, opowieści napisanej w formie sfabularyzowanego pamiętnika Cixi, kobiety, która podejmuje brzemię regencji po śmierci Xianfenga jako świadoma odpowiedzialności za losy Chin (Anchee Min, Cesarzowa Orchidea, Albatros, kilka wznowień).

W historycznych opracowaniach naukowych i popularnonaukowych Cixi przedstawiana jest różnie. Często już warstwa słowna wpisuje się w kreowanie nieprzychylnego nastawienia: rzadziej mówi się o niej ,inteligentna i przenikliwa”, częściej „sprytna i przebiegła”, a jej stronników nazywa się „poplecznikami” lub „kliką”.

Można tu przytoczyć kilka wybranych opinii: John K. Fairbank przyznając, że „pod regencją młodej cesarzowej wdowy (Cixi) nowi przywódcy w Pekinie zdołali w 1864 pokonać tajpingów (czyli przywrócić pokój - uwaga AŁ) i zapewnić dynastii «nowy oddech»"2, nazywa ją dalej na tej samej stronie ,ignorantką i obskurantką".

Z kolei prof. Jakub Polit w popularnonaukowej książce Chiny w serii Historia państw świata $w X X$ wieku pisze: „Cixi, kobieta ogromnej siły charakteru i mistrzy-

2 John King Fairbank, Merle Goldman, China. A New History, The Belknap Press of Harvard University Press, Cambridge 2006, s. 213. 
ni intrygi, lecz o ciasnych horyzontach i zupełna ignorantka, jeśli chodzi o świat niechiński, odegrała fatalną rolę w dziejach swego kraju...", choć kilka wierszy wcześniej ocenia, że stawienie czoła wyzwaniom, jakie się pojawiły wówczas przed rządzącymi w Chinach, ,byłoby trudne nawet dla przywódcy bardzo wybitnego"3. W indeksie osób autor ocenia ją ,jako znaną z chciwości i braku skrupułów”, przy nazwiskach postaci z nią związanych określa je mianem popleczników.

W zwięzłej historii Chin i Tajwanu Roman Sławiński z kolei mówi „o represjach wobec reformatorów na rozkaz cesarzowej Cixi”, a dalej, przy omawianiu powstania Yihetuanów: ,zostali wykorzystani przez przebiegłą cesarzową Cixi”.

Jonathan Fenby w skrótowym podsumowaniu okresu od stłumienia powstania tajpingów do końca XIX w., nie wdając się w rozróżnienie wcześniejszych i późniejszych wysiłków reformatorskich, zauważa: „Na przełomie wieków ogłoszono wprowadzenie zmian dotyczących szkolnictwa, administracji politycznej, przemysłu, prawa i budżetu. Jednak reakcyjnie nastawiona cesarzowa wdowa Cixi zablokowała reformy, dokonując przewrotu"s.

Nieco odmienna opinia pojawiła się w zbiorowej pracy sinologów radzieckich: „Tz’u Si odznaczała się nieprzeciętnym umysłem i energicznym władczym charakterem"'. Jednak w dalszych partiach książki Cixi jest również określana jako reakcyjna.

Jung Chang podejmuje zadanie sprawiedliwszej oceny Cixi na podstawie starannie zebranej literatury (imponująca bibliografia obejmuje ponad 300 pozycji) $\mathrm{i}$ - co istotniejsze - badania źródeł historycznych. Objęła nimi nowo dostępne źródła chińskich archiwów, zarówno chińsko- jak i mandżurskojęzyczne, m.in. zgromadzone w Pierwszym Archiwum Historycznym Chin w Pekinie, gdzie przechowywane są dokumenty dynastii Qing. Warto przy tym wspomnieć, że pracownicy naukowi archiwum uskarżali się na brak specjalistów znających język mandżurski (usłyszałam tę opinię w 2002 r.). Godna w tym kontekście uwagi jest wzmianka, że Cixi nie znała mandżurskiego przed pojawieniem się na dworze i dopiero tam zaczęła się go uczyć (kolejne świadectwo kulturowej asymilacji Mandżurów). Autorka cytuje wiele dzienników i pamiętników osób związanych z otoczeniem dworu, a jednym ze źródeł najczęściej przytaczanych i interpretowanych pozytywnie wobec cesarzowej jest dziennik wielkiego nauczyciela cesarza Guangxu

3 Jakub Polit, Chiny, Wydawnictwo Trio, Warszawa 2004, s. 25, 389, 400 i in.

${ }^{4}$ Roman Sławiński, Historia Chin i Tajwanu, Wydawnictwo Askon, Warszawa 2002, s. 70.

5 Jonathan Fenby, Czang Kaj-szek i jego Chiny, thum. Jarosław Włodarczyk, Wydawnictwo Dolnośląskie, Wrocław 2010, s. 41.

${ }^{6}$ S.L. Tichwiński (red.), Historia nowożytna Chin, tłum. Maria Wolska, Książka i Wiedza, Warszawa 1978, s. 243. 
Weng Tinghe, który nie należał do jej sprzymierzeńców, był jednak człowiekiem bardzo lojalnym.

Za przełomowe dla zasadniczego przewartościowania ocen Cixi uważa Jung Chang informacje, do których w latach 80 . ubiegłego stulecia dotarli historycy chińscy w archiwach japońskich, a dotyczyły one Kang Youweia, o czym wspomniałam. Autorka zebrała zatem w celu przeprowadzenia swojej gruntownej analizy ogromny, w znacznej mierze dotychczas niewykorzystywany materiał, zaznaczając, że wiele źródeł archiwalnych pozostawało poza Chinami nieznanych.

Dla założonej konfrontacji rozpowszechnionej czarnej tezy z bronionym przez autorkę obrazem najważniejsza wydaje się dokonana przez Jung Chang korekta następujących ocen.

Po pierwsze, autorka kwestionuje opinie o zachowawczości Cixi. Dokumentuje zrozumienie Cixi dla pierwszych prób reformy Chin, podjętych w latach 60 . XIX w., po przywróceniu w kraju pokoju (po drugiej wojnie opiumowej i powstaniu tajpingów). Dotyczyły one m.in. wprowadzenia do systemu edukacji elementów nauk ścisłych i przyrodniczych, unowocześnienia armii i próby zrewolucjonizowania transportu poprzez budowę kolei. Wbrew powszechnemu przekonaniu reformatorskie programy nie tylko nie były przez Cixi hamowane, lecz właśnie przez nią inspirowane, a ich sukces lub niepowodzenie wynikały z oporu niechętnych reformom i cesarzowej osób zajmujących wysokie stanowiska. Podobnie było w późniejszym okresie, w czasie drugiej regencji, kiedy m.in. podjęto modernizację floty. Najtrudniejszy do oceny jest udział Cixi w wydarzeniach ruchu ,100 dni reform" (1898), przy czym autorka w nowatorski sposób opisuje rolę cesarzowej w przygotowaniu inicjującego ruch edyktu cesarskiego Podstawy polityki państwa (s. 300) oraz wspólne z Guangxu przygotowywanie dalszych projektów. Szczególnie kontrowersyjne, przypisywane Cixi działania, które doprowadziły do tragicznego finału ruchu, wynikały, według wywodu autorki, z intryg Kang Youweia, przedstawionego bardzo krytycznie jako człowiek, który cynicznie dążył za pomocą swoich reform wyłącznie do zdobycia władzy. Cixi ,jako pierwsza doceniła jego talenty i zaczęła go wspierać”, i zgadzała się z jego reformatorską polityką. Obdarzona intuicją, którą należałoby określić jako polityczną przenikliwość, przejrzała jednak jego intencje, a władzy nie zamierzała mu oddawać (s. 311).

To ona wreszcie w ostatnim okresie życia w początkach XX w. nakazała zainicjowanie - oczywiście historycznie spóźnione - reform zmierzających do wprowadzenia ustroju parlamentarnego i konstytucji, edukacji kobiet oraz zniesienie tortur i najbardziej okrutnych kar. Wprowadziła także zakaz krępowania stóp dziewczynkom.

Po drugie, Jung Chang sprzeciwia się opinii o ksenofobii cesarzowej. Przywołując utrwalone przekonanie o zamykaniu się jej na świat zewnętrzny i na kontakty 
z cudzoziemcami, dowodzi, że Cixi bardzo wcześnie zdała sobie sprawę ze strat, jakie przynosi Chinom polityka izolowania się od zagranicy. To właśnie cesarzowa inicjowała, a nawet nakazywała pracę na rzecz przyswojenia Chinom przydatnych wynalazków i sposobów działania państw zachodnich (nauki ścisłe, organizacja nowoczesnego poboru ceł, unowocześnienie transportu i inne) oraz otwarcia się na pewne formy kontaktów z Zachodem. Opowiadała się za zorganizowaniem instytucji szkolącej Chińczyków do takich kontaktów, łącznie z nauką języków obcych, oraz wysłaniem po raz pierwszy grupy chińskich studentów na naukę do Stanów Zjednoczonych. Autorka broni Cixi, twierdząc, że to właśnie wysiłki cesarzowej napotykały opór innych (książę Chun, ,przywódca ksenofobicznej frakcji, stanowił największą przeszkodę dla prowadzonej przez cesarzową polityki otwartych drzwi" - s. 139). W późniejszych dekadach to ona uważała za konieczne sprowadzenie z zagranicy maszyn dla fabryk i transportu oraz okrętów, dla tworzonej floty wojennej; postulowała także zatrudnienie doradców zagranicznych. Wreszcie po klęsce, jaką była interwencja armii ośmiu państw kończąca powstanie Yihetuanów, Cixi, według przytoczonych przez autorkę faktów, uznała za błędną swoją poprzednią politykę, która doprowadziła do tragicznego rozwoju wydarzeń, i wydała dekret „o potrzebie przyjmowania tego, co lepsze, od obcych krajów, które stały się bogate i silne" (s. 399)7. W ostatnich latach Cixi dopuściła cudzoziemców do bezpośrednich kontaktów, przyjmując przedstawicieli obcych państw i zapraszając na dwór cesarski cudzoziemskie artystki i arystokratki.

Po trzecie, Jung Chang nie zgadza się z zarzutami, jakoby cesarzowa była uległa wobec mocarstw i wyprzedawała Chiny, i wskazuje tu na niedostrzeganie podejmowanej przez nią obrony interesów cesarstwa w konfliktach z mocarstwami. Autorka podkreśla, że Cixi tam, gdzie mogła, broniła terytorium, np. odbierając Rosji zagarniętą część Xinjiangu w rejonie Ili, jak też ubolewała nad utratą ziem za Amurem, przejętych przez Rosję na mocy traktatu ajguńskiego w 1858 r., na co wówczas nie mogła mieć wpływu. Po klęsce wojny z Japonią wobec dalszego zagrożenia z jej strony Cixi starała się przyciągnąć Rosję, oferując budowę kolei w Mandżurii, świadoma możliwych negatywnych konsekwencji, takich jak wzrost wpływów rosyjskich na tych terenach.

Bardzo krytykowana była decyzja Cixi o momencie zakończenia wojny z Francją (np. Sun Yat-sen w Zasadzie narodowej ${ }^{8}$ ): cesarzowa uważała, że po odniesieniu sukcesu militarnego dalsze walki nie służą dobru państwa, narażając je na straty, a rezygnacja z wasalnej zależności Wietnamu, stale niepokojącego grani-

${ }^{7}$ Autorka cytuje Yihetuan dangan shiliao, Archiwum Dynastii Ming i Qing, Pekin 1979, t. 2. s. 914-916.

8 Sun Yat-sen, Trzy zasady ludu, Szkoła Wyższa Psychologii Społecznej, Wydawnictwo Akademickie Sedno, Warszawa 2014, s. 91. 
cę z cesarstwem, nie przynosi uszczerbku interesom Chin. Zupełnie inne było jej stanowisko w wojnie $\mathrm{z}$ Japonią: kontynuowanie walk uważała za konieczne i stanowczo sprzeciwiała się ustępstwom. Żądała twardych negocjacji traktatu z Shimonoseki i dzięki wykorzystaniu wsparcia mocarstw europejskich, zaniepokojonych umocnieniem się Japonii, uzyskała złagodzenie warunków traktatu. Niemniej jednak właśnie ją oskarżano o przyczynienie się do klęski.

Autorka nie próbuje pominąć nagannych postępków cesarzowej. Pisze o jej zamiłowaniu do zbytku, pięknych przedmiotów, drogich prezentów i biżuterii. Nie próbuje tuszować sprawy funduszy na odrestaurowanie obecnego Pałacu Letniego, choć wyjaśnia przesadny charakter oskarżeń. Nie usprawiedliwia okrutnego potraktowania ulubionej konkubiny Guangxu. Do wielu faktów - a książka zawiera ich mnóstwo - dodaje interpretację lub komentarz, czasem bardzo rozbudowany, przesadnie jednakże akcentując wnioski przemawiające na korzyść bohaterki. Przyjmując w nich punkt widzenia dynastii, o czym wspomniałam, Jung Chang pomija wysiłki emancypacji narodowej chińskich patriotów. O Sun Yat-senie wspomina bez cienia sympatii. Walorem książki są liczne przykłady zwyczajów i życia codziennego dworu z opisami wplecionymi niemal fabularnie.

We wspomnianej obszernej bibliografii wiele jest pozycji opublikowanych w ostatnich dekadach. Autorka zastrzegła, że podane przez nią daty wydań odnoszą się do tych, z których korzystała, a nie do roku ukazania się tytułu po raz pierwszy. Nie można więc na tej podstawie potwierdzić tezy, że postać Cixi jest przedmiotem zwiększonego zainteresowania, na co wskazują inne informacje. O dokonującej się rewizji ocen mówili już dziesięć lat temu moi chińscy znajomi, wskazując na ukończoną w grudniu 2004 r. książkę autora spokrewnionego z rodziną cesarzowej - Yehenala Genzhenga ${ }^{9}$, w bibliografii wymienioną we wznowieniu z 2007 roku. Jej autora, noszącego to samo nazwisko, co rodowe nazwisko Cixi, Jung Chang umieszcza wśród osób, z którymi się konsultowała. Warto dodać, że próby rewizji obiegowych, zwłaszcza wśród Chińczyków, negatywnych ocen panowania mandżurskiej dynastii Qing były podejmowane przynajmniej od kilkunastu lat. W tym aspekcie autorka nie jest zatem tak odkrywcza, jak sama sugeruje.

Oddanie dość zawiłego wywodu autorki w polskim przekładzie było niełatwym zadaniem. Tłumaczka operuje bogatą polszczyzną i starannym doborem określeń. Nie uniknęła ona jednak pewnych nieścisłości. Czy wynikają one $\mathrm{z}$ angielskiego oryginału, czy z braku wiedzy o Chinach, trudno ustalić, ponieważ w informacjach wydawniczych nie ma wzmianki o konsultacji sinologicznej. Dotyczy to np. opisu letniej rezydencji dynastii Qing - jednego ze sztandarowych zabytków z tzw. zewnętrznymi świątyniami, gdzie jest replika Pałacu Potali z Lhasy - w książ-

9 Yehenala Genzheng, Hao Xiaohui, Wosuo zhidaode Cixi taihou, Jincheng Chubanshe, Beijing 2005. 
ce zredukowanej do „pawilonu myśliwskiego”. Jeden z symboli Pałacu Letniego Yiheyuan, słynny most 17 łuków, traci w polskim wydaniu aż $10 \mathrm{z}$ nich i jest mostem siedmiołukowym (w książce zamieszczona jest ilustracja, na której most jest na pierwszym planie). Wymienne używanie chińskich nazwisk i imion jest dla polskiego czytelnika mylące. Można było takich niedociągnięć uniknąć, konsultując tekst z sinologiem - o konsultację taką zadbali np. thumacze i wydawca $\mathrm{Ce}$ sarzowej Orchidei (konsultantem była Teresa Lechowska), pozycji, wydawałoby się, znacznie mniej ambitnej - albo powierzyć tłumaczenie sinologowi, sprawniej i pewniej poruszającemu się w chińskich realiach ${ }^{10}$.

${ }^{10}$ Już po oddaniu recenzji do druku znaleźliśmy w Bibliotece Orientalistycznej Uniwersytetu SPWS gazetowy dodatek z 1977 roku przypominający, że postać Cixi, jako negatywny przykład żądzy władzy kobiet, była po śmierci Mao (1976 r.) wykorzystywana w politycznej rozgrywce przeciw jego ostatniej żonie i przywódczyni Rewolucji Kulturalnej Jiang Qing. Dodatek do lokalnej gazety „Chengde Ribao" (czyli miasta, gdzie znajdowała się wspomniana wyżej letnia rezydencja dynastii) przytacza wypowiedzi Jiang Qing, powołujące się m.in. na Cixi jako kobietę sprawującą najwyższą władzę w państwie, co służyło jej jako uzasadnienie własnych ambicji zajęcia podobnej pozycji. Jest to jeden z przykładów ukazujących się wówczas - także w prasie centralnej - tendencyjnych tekstów i rysunków, w któych obrzucano Cixi najbardziej negatywnymi w retoryce lat 70. epitetami, uznawano ją za winną wszelakich zbrodni wobec narodu, a towarzyszące tekstom karykatury wyjątkowo złośliwie przedstawiały ją jako postać odrażającą. Samo skojarzenie Jiang Qing z Cixi potęgowało negatywny odbiór jej osoby. 